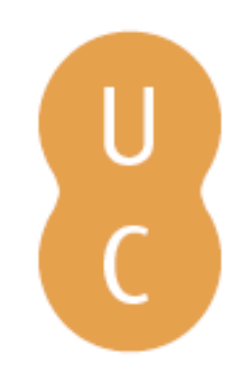

\title{
nombalina
}

\section{The Spark Wildfire Prediction System}

$\begin{array}{ll}\text { Autor(es): } & \text { Hilton, J. E.; Sullivan, A. L.; Swedosh, W.; Cruz, M. G.; Plucinski, M. P.; } \\ \text { Hurley, R. J.; Huston, C.; Prakash, M. }\end{array}$

Publicado por: Imprensa da Universidade de Coimbra

URL

persistente: URI:http://hdl.handle.net/10316.2/44639

DOI: $\quad$ DOI:https://doi.org/10.14195/978-989-26-16-506_122

Accessed : $\quad$ 26-Apr-2023 14:13:48

A navegação consulta e descarregamento dos títulos inseridos nas Bibliotecas Digitais UC Digitalis, UC Pombalina e UC Impactum, pressupõem a aceitação plena e sem reservas dos Termos e Condições de Uso destas Bibliotecas Digitais, disponíveis em https://digitalis.uc.pt/pt-pt/termos.

Conforme exposto nos referidos Termos e Condições de Uso, o descarregamento de títulos de acesso restrito requer uma licença válida de autorização devendo o utilizador aceder ao(s) documento(s) a partir de um endereço de IP da instituição detentora da supramencionada licença.

Ao utilizador é apenas permitido o descarregamento para uso pessoal, pelo que o emprego do(s) título(s) descarregado(s) para outro fim, designadamente comercial, carece de autorização do respetivo autor ou editor da obra.

Na medida em que todas as obras da UC Digitalis se encontram protegidas pelo Código do Direito de Autor e Direitos Conexos e demais legislação aplicável, toda a cópia, parcial ou total, deste documento, nos casos em que é legalmente admitida, deverá conter ou fazer-se acompanhar por este aviso.

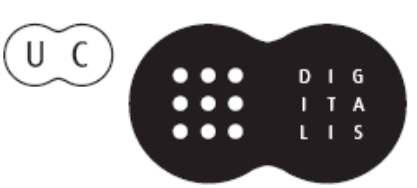




\section{ADVANCES IN}

\section{FOREST FIRE RESEARCH}

\section{8}

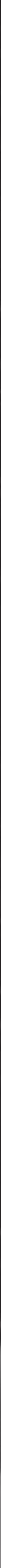




\title{
The Spark Wildfire Prediction System
}

\author{
J. E. Hilton ${ }^{1 *}$; A. L. Sullivan*2; W. Swedosh ${ }^{1} ;$ M. G. Cruz ${ }^{2}$; M. P. Plucinski²; R. J. Hurley ${ }^{2}$; C. \\ Huston $^{1} ;$ M. Prakash ${ }^{1}$ \\ ${ }^{1}$ CSIRO, Clayton, VIC 3168, Australia, \{james.hilton@csiro.au*\} \\ ${ }^{2}$ CSIRO, Canberra, ACT 2601, Australia, \{andrew.sullivan@csiro.au\}
}

\begin{abstract}
Spark is a computational platform for modelling wildfire behavior, developed for research, risk assessment and operational use. The platform has been designed for flexibility, allowing users to define wildfire models, process weather streams and spatial data, and visualize and analyze the resulting simulations. The core fire propagation solver is a raster-based level set method that calculates the progression of a fire perimeter over given terrain layers and allows the creation, merging and interaction of any number of individual fire perimeters. Propagation in different fuel types is implemented using text-based scripts that define the fire behavior and rate-of-spread, rather than having pre-determined models built into the system. This gives the system flexibility to implement any available fire behavior models. The system is currently being used to research and implement many aspects of fire behavior including the development of new rate-of-spread models, integration with meteorological and remote sensing data and the modelling of firebrand dynamics and fire-atmosphere interaction. The system is freely available to researchers, practitioners and managers in the wildfire community.
\end{abstract}

Keywords: Wildfire modelling, bushfire, simulation, software

\section{Introduction}

Wildfires are a worldwide threat, causing major environmental damage and posing significant danger to lives and infrastructure when impacting on urban interfaces. Spark is a computational platform that can rapidly model two-dimensional wildfire spread for research, risk assessment and operational use (Miller et al., 2015). The platform has been developed to be entirely user-configurable at all levels, from the behaviour of the fire down to the central workflow for running and processing wildfire simulations. This flexibility allows users complete control in processing input layers and data, implementing wildfire models, post-processing the results of simulation and visualising data. The system leverages the power of new graphical processing units (GPUs) for rapid geoprocessing allowing complex fire behaviour models to be implemented for multiple fuel types. Spark can also spatially ensemble the results of multiple predictions to build statistical maps for risk assessment and fire management.

\section{Architecture and Configurability}

The core of Spark is a fire propagation solver, based on a computational level set method (Hilton et al., 2015). This raster-based method manages the creation, movement and merging of fire perimeters over a set of given terrain layers according to user-defined empirical fire spread models. The level set method is particularly well suited to modelling fire spread as it can handle irregular boundary conditions, run at any required resolution and handle the interaction of any number of individual fire perimeters, for example, multiple spot fire ignitions ahead of a fire front. 


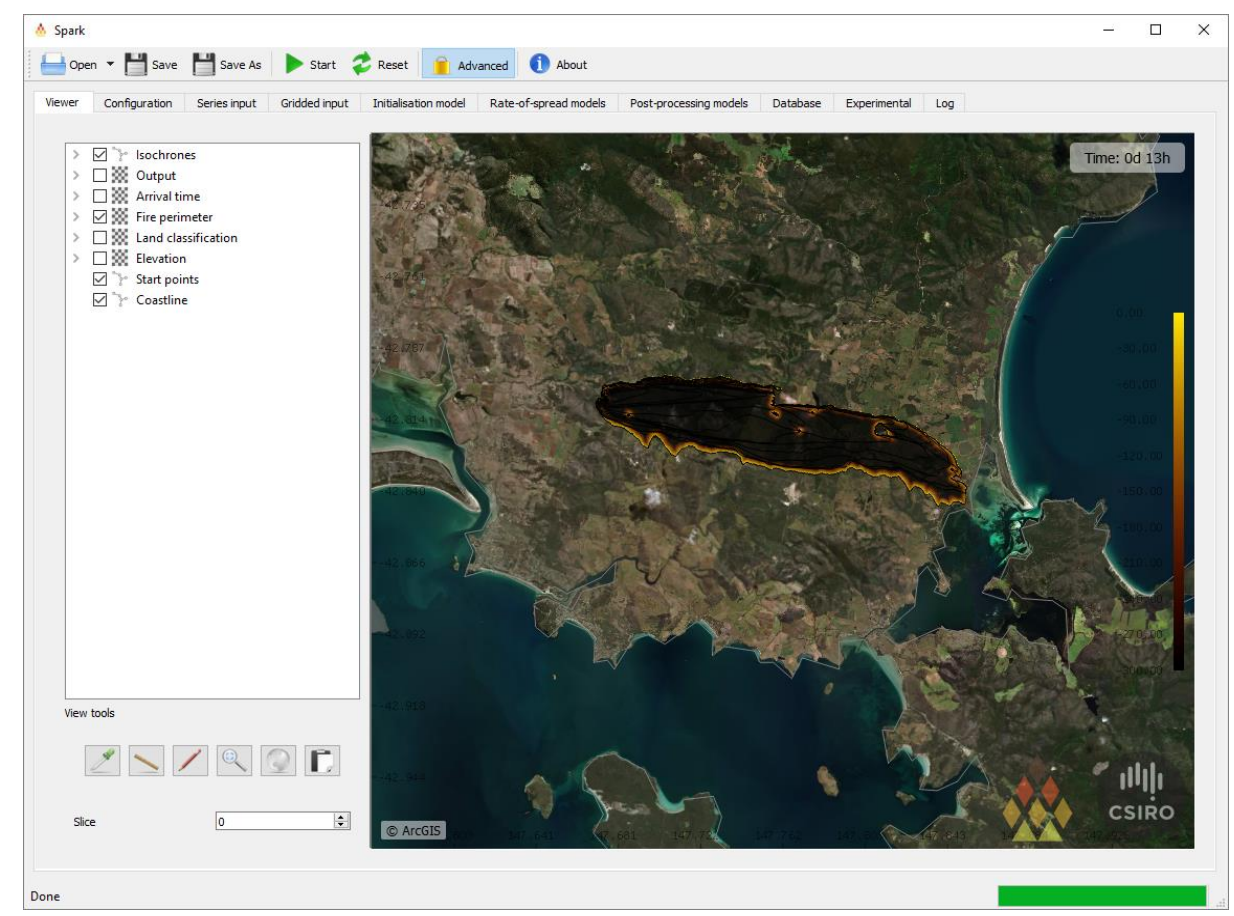

Figure 1 - Spark configured as a graphical-user-interface suitable for operational usage showing a fire in Tasmania, Australia.

The fire propagation solver can be configured in various user-dependent ways, such as within an interactive graphical-user interface (Figure 1), a workflow-based system for research (Figure 2) or a headless command line version for servers and cloud computation. The system is supported on both the Linux and Windows platforms. Fire front propagation in different fuel types is implemented using text-based scripts to define the fire behaviour and rate-of-spread, rather than having pre-determined models built into the system. This gives the system flexibility to implement any available fire behaviour models and fire templates, such as elliptical or more complex shapes, and to enable testing of new models (Hilton et al. 2016). We have currently implemented most fire rate-of-spread models used operationally in Australia (Cruz et al. 2015), examples of which are available on our research website (Spark, 2018) as well as version of the software, documentation and modelling guides.

The data layers required for these fire rate-of-spread models can be loaded into the system in any common geospatial formats. The layers are transparently re-projected and interpolated to a required resolution within Spark. The system can also pre and post-process any combination of these layers using user defined scripts. For example, a pre-processing implementation has been developed which directly reads remote sensing data tiles from Landsat imagery and converts these into fuel condition data suitable for fire simulations in Eucalypt forest (Massetti et al. 2018). Post-processing can include models for combustion, radiant heat flux and flame height, or models for impact assessment with asset layers. 


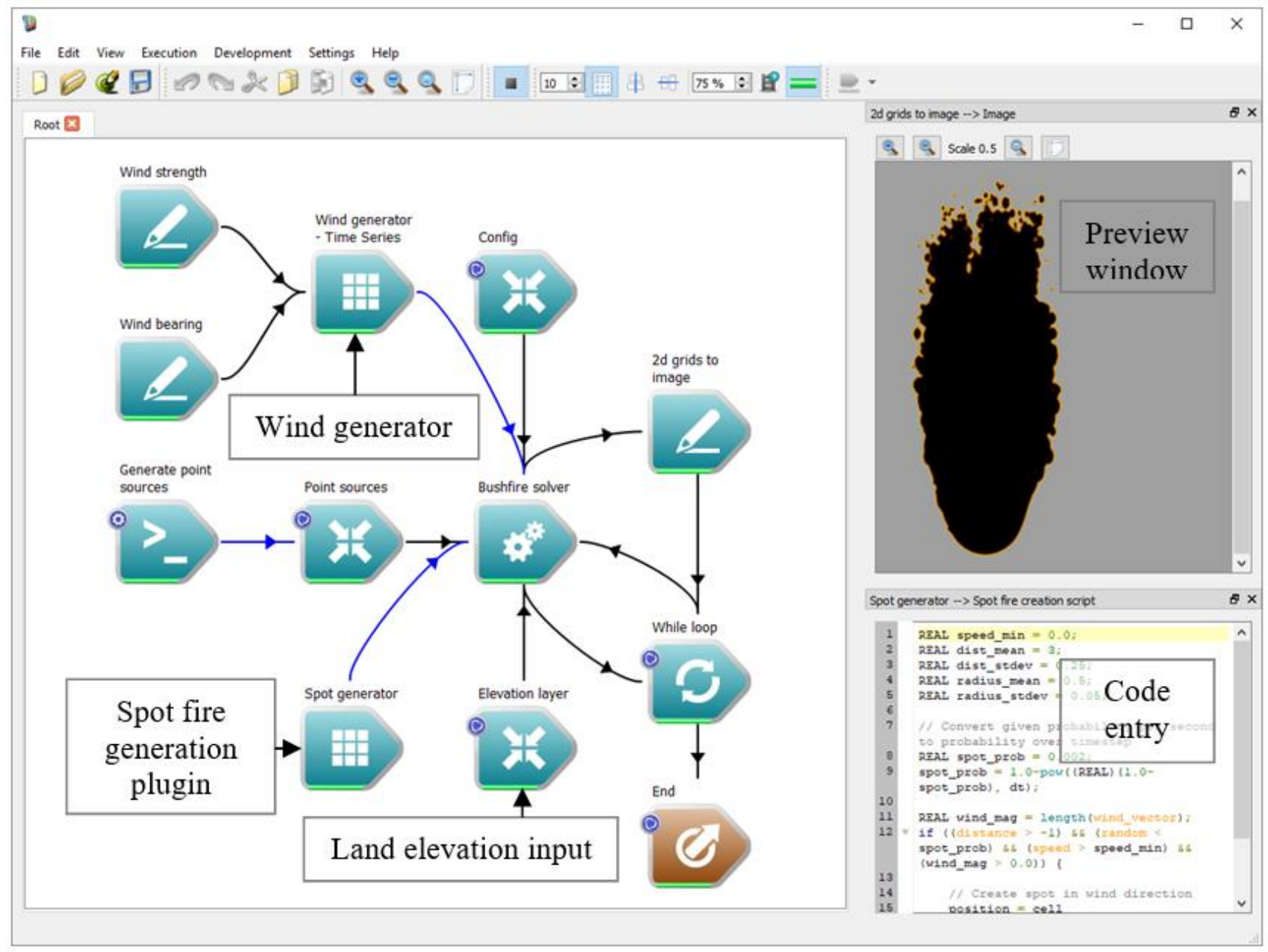

Figure 2 - Spark workflow in the Workspace editor.

Surrounding the core propagation algorithm is a modular geospatial processing architecture based on a workflow technology called Workspace developed by CSIRO (Watkins et al., 2017). This workflow framework allows Spark to be easily configured in multiple ways for different purposes, for example, development and research of new fire behaviour models. An example workflow canvas is shown in Figure 2 where the individual elements of the workflow are blue boxes. These elements include modules to create the input starting conditions, generate the wind field and input data layers. The core fire propagation solver supports modular plug-ins for various aspects of fire behaviour, such as the firebrand generation model shown in Figure 2 A preview of the simulation results is shown in a window on the upper right-hand side and the user-defined script for configuring the firebrand model is shown on the lower right-hand side.

The system can also be used to quantify the risks from wildfires in hypothetical scenarios by running ensembles of input or weather conditions. These ensembles can be configured and composited in various ways, for example, varying the starting location of a fire and computing the resulting fire footprints into a probability map, as shown in Figure 3. The heat-map shown in the left-hand figure is shaded by frequency of fire impact. As with all models in Spark the composition and processing of the ensembles is user-defined, with Spark providing the ability to calculate global metrics over each ensemble, or to calculate a running spatial ensemble over all ensemble members. The results can be written to a PostGIS database, if required, for further downstream processing. 


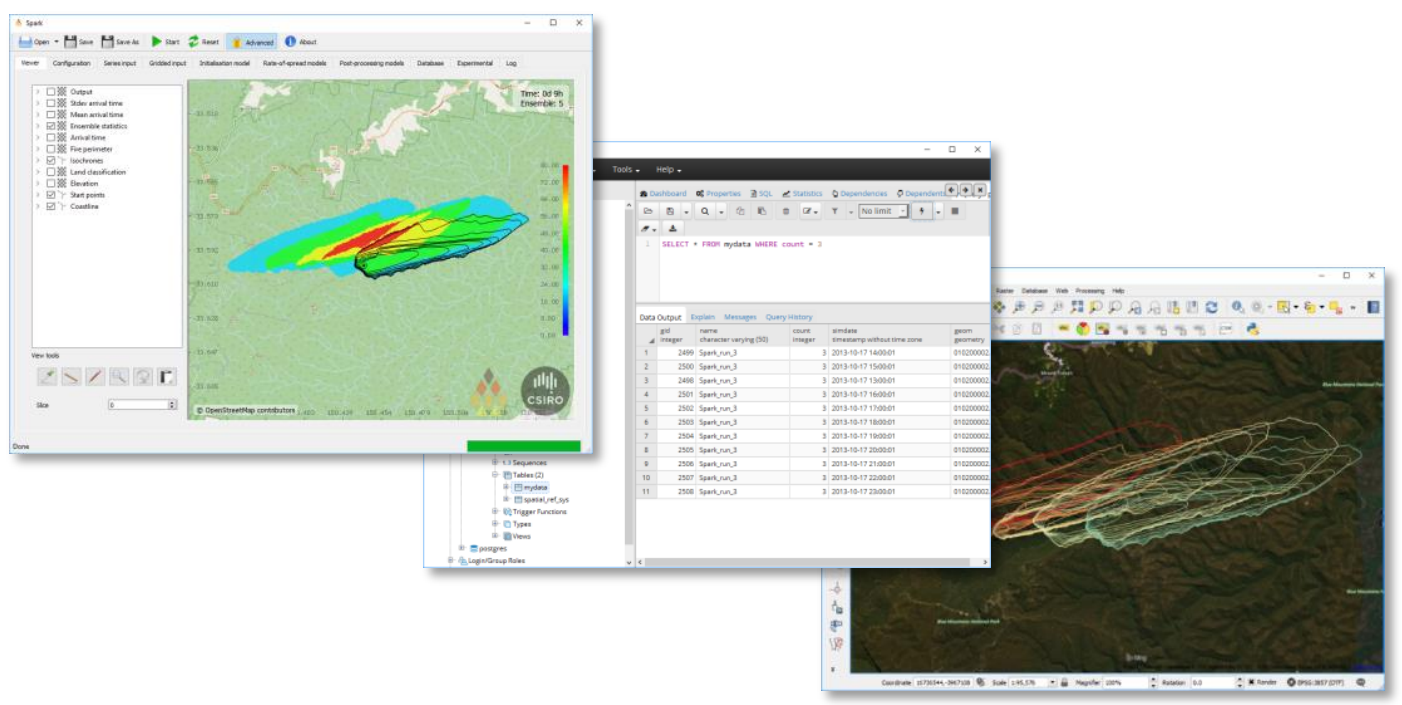

Figure 3 - Spark ensemble analysis. The Spark graphical-user-interface (left) showing impact frequency from several possible fires as a coloured heat-map. The fire isochrones can be directly written to PostGIS (centre) and visualised in and external GIS tool (right).

Sub-models currently available within the framework include a mass-conservation wind correction model, a firebrand transport and ignition model and a fuel break model for firebreaks, roads and waterways, an example of which is shown in Figure 4. The fuel break model uses a set of line features of inputs which stops the spread of fires at these lines until a user-defined condition is met. In the example shown in Figure 4, a set of roads is used as input and the road has a probability of being breached based on a constant hazard function. As the rule for breaching is probabilistic an ensemble of simulations has been run to find the probability of the fire arriving at each point on the map. This is shown as a heat-map of impact probability.

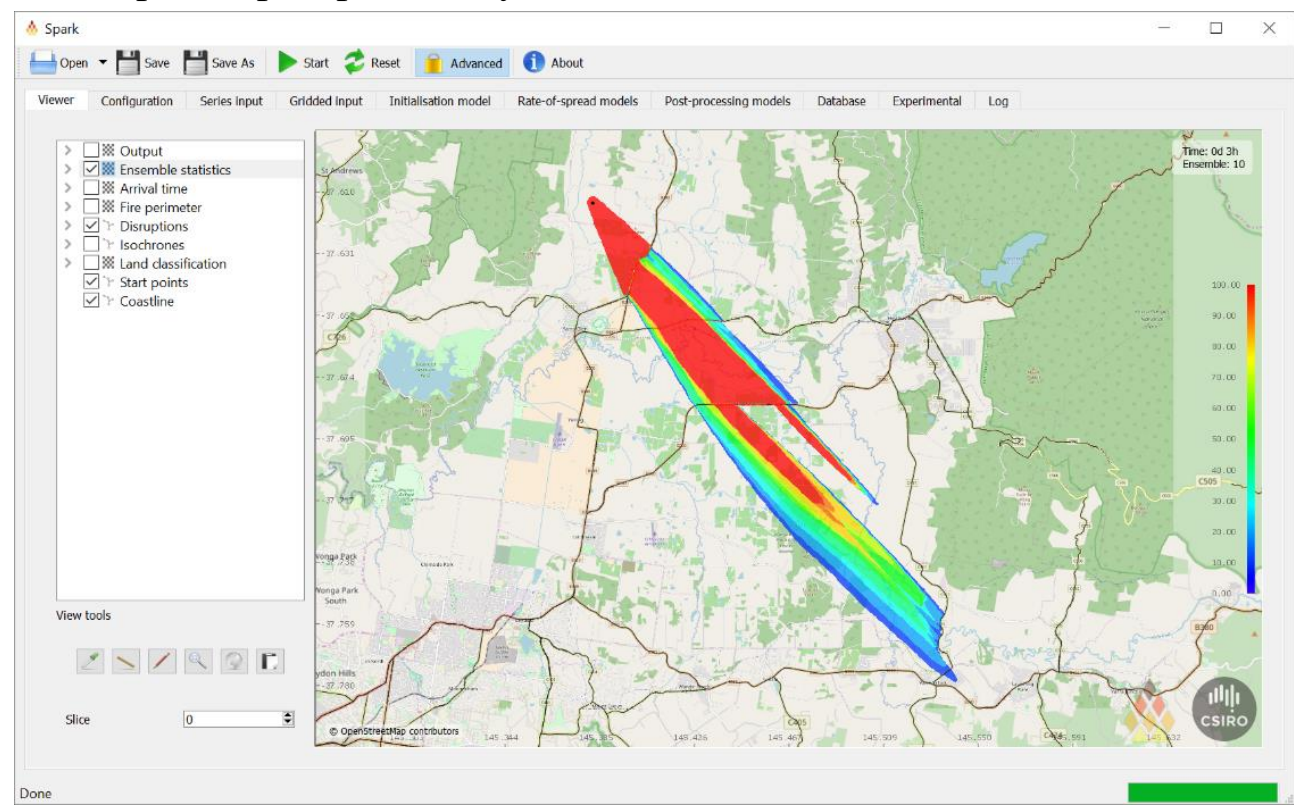

Figure 4 - Ensemble of simualtions from a set of fires with a random probability of crossing a road. The shaded heat map shows the impact probability of a fire arriving at a given point.

Spark harnesses the power of new graphical processing unit technology (GPUs). Almost all current computers have graphical processing units which, if used for computation, can carry out multiple calculations in parallel. This can result in speed increases hundreds of times greater than standard 
computations on the central processing unit (CPU) of a computer. This translates into the ability to run complex fire behaviour algorithms at high spatial resolutions in a very short computational time. Additionally, such GPUs are available as a cheap, reliable and scalable resource on several cloudbased systems such as Amazon Web Services (AWS).

\section{Research and Operation}

An aim of developing the Spark system was to connect the research community with operational users by creating a common platform through which new research could be easily tested and deployed. We are currently using Spark for internal research as well as collaborating with several university groups to develop new methods and models for predicting fire behaviour. This includes research into the sensitivity to meteorological data, direct integration of remotely sensed data products into fire simulations, firebrand dynamics, radiant heat flux modelling for urban interfaces (Hilton et al. 2017), new methods for modelling firebreaks (Swedosh et al. 2017) and fire-atmosphere interaction such feedback effects from the fire (Hilton et al., 2018). We are also researching more efficient methods for ensemble modelling and web-based deployment on cloud infrastructure for large sets of ensembles (Garg et al., 2018).

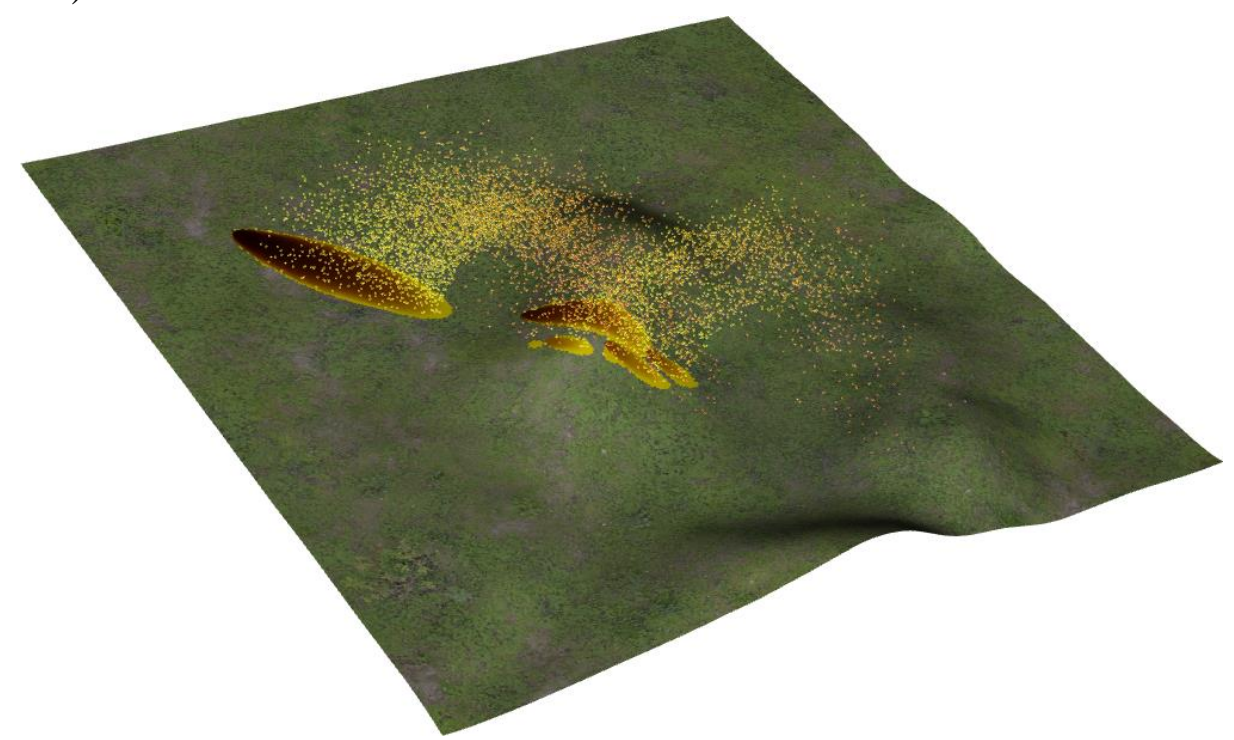

Figure 5 - Three-dimensional visualisation of Spark firebrand modelling system. Each firebrand is individually controlled in the model using a user-defined script.

An example of a research module is the Spark firebrand processor, a visualisation of which shown in Figure 5. This module allows the user to define models for the creation and transport of firebrands as well as the impact with the ground and subsequent chance of spot-fire creation. The models are defined in a similar way to the rate-of-spread models, for example, the user specifies the acceleration of the firebrand in a script based on properties of the firebrand, such as time since ignition, and local fields, such as the wind vector at the location of the firebrand. We are currently collaborating with university groups to research and develop models for firebrand distribution and spot formation using the Spark platform.

\section{Conclusion}

Spark has been designed as a platform for rapid and configurable modelling of two-dimensional fire spread. The system can be used for research or to interactively provide a visual awareness of the potential impact of a wildfire, enabling early warnings, ability to manage resources and guide mitigation strategies. Alternatively, the system can be configured as a risk modelling system capable 
of generating spatial risk metrics from large ensembles of potential wildfires. The modular nature of the system allows configurability and customisation for the end user, or the ability for developers to add new types of more complex fire behaviour models. The system is freely available to the research and operational community (Spark, 2018).

\section{References}

Cruz MG, Gould JS, Alexander ME, Sullivan AL, McCaw WL, Matthews S (2015) Empirical-based models for predicting head-fire rate of spread in Australian fuel types. Australian Forestry 78, 118 158.

Garg S, Forbes-Smith N, Hilton JE, Prakash M, (2018) SparkCloud: A Cloud-Based Elastic Bushfire Simulation Service, Remote Sensing, 10, 74

Hilton JE, Leonard J, Blanchi R, Newnham G, Opie K, Rucinski C, Swedosh W (2017) Simulation of spot fire coalescence with dynamic feedback, In Syme, G., Hatton MacDonald, D., Fulton, B. and Piantadosi, J. (eds) MODSIM2017, 22nd International Congress on Modelling and Simulation. Modelling and Simulation Society of Australia and New Zealand, 1104-1110.

Hilton JE, Miller C, Sullivan AL, Rucinski C (2015) Effects of spatial and temporal variation in environmental conditions on simulation of wildfire spread, Environmental Modelling and Software, 67, 118-127

Hilton JE, Miller C, Sullivan AL (2016) A power series formulation for two-dimensional wildfire shapes. International Journal of Wildland Fire, 25, 970-979

Hilton JE, Sullivan AL, Swedosh W, Sharples J, Thomas C (2018) Incorporating convective feedback in wildfire simulations using pyrogenic potential, Environmental Modelling \& Software, 107, 1224

Massetti A, Yebra M, Hilton J, Rüdiger C, (2018) Determining Spatio-Temporal Fuel Accumulation Using the Vegetation Structure Perpendicular Index from Optical Remote Sensing: Application to Dynamic Fire Spread Simulations, In D. X. Viegas (Ed.), Advances in Forest Fire Research

Miller C, Hilton JE, Sullivan AL, Prakash M (2015) Spark - A Bushfire Spread Prediction Tool. In: Denzer R., Argent R.M., Schimak G., Hřebíček J. (eds) Environmental Software Systems. Infrastructures, Services and Applications. ISESS 2015. IFIP Advances in Information and Communication Technology, 448. Springer, Cham

Spark research website (2018), https://research.csiro.au/spark/

Swedosh W, Hilton JE, Prakash M (2017) S Modelling Firebreaks in a Two-Dimensional Dynamic Fire Spread Simulator, In Syme, G., Hatton MacDonald, D., Fulton, B. and Piantadosi, J. (eds) MODSIM2017, 22nd International Congress on Modelling and Simulation. Modelling and Simulation Society of Australia and New Zealand, 1104-1110.

Watkins D, Thomas D, Hetherton L, Bolger M, Cleary PW (2017) Workspace - a Scientific Workflow System for enabling Research Impact, In Syme, G., Hatton MacDonald, D., Fulton, B. and Piantadosi, J. (eds) MODSIM2017, 22nd International Congress on Modelling and Simulation. Modelling and Simulation Society of Australia and New Zealand, 1-7 